Acta Manilana 64 (2016), pp. 1-7

Printed in the Philippines

ISSN: 0065-1370

\title{
Molecular confirmation and taxonomy of the Rubiaceous Mycetia apoensis (Elmer) Govaerts
}

\author{
John Christopher C. Villanueva ${ }^{1}$, Remigio S. Callanta Jr. ${ }^{1}$, Jasmin Aei F. Neptuno ${ }^{1}$, \\ Maryneil A. Verin ${ }^{1}$, Porferio S. Bangcaya ${ }^{3}$, Vincent Louie D. Cabelin ${ }^{4}$, \\ $\mathcal{E}$ Grecebio Jonathan D. Alejandro* ${ }^{* 1,2}$
}
${ }^{1}$ Department of Biological Sciences, College of Science; ${ }^{2}$ Research Center for the Natural \& Applied Sciences, University of Santo Tomas, 1015 Manila, Philippines; ${ }^{3}$ College of Teacher Education, Biological Science Department, University of Antique, Tibiao Campus, 5707 Antique, Philippines;
${ }^{4}$ College of Arts and Sciences, Notre Dame of Dadiangas University, General Santos City, 9500 South Cotabato, Philippines

\begin{abstract}
The little known endemic Philippine Rubiaceae Adenosacme apoensis Elmer was transferred to the genus Mycetia Reinw. based on herbarium specimens. Also, Mycetia apoensis was once thought as conspecific with $M$. cauliflora. To date, $M$. apoensis lacks comprehensive vegetative and reproductive descriptions to fully understand the species and be able to delineate from other members of Mycetia. To verify the generic affiliation of the species with more certitude, two chloroplast markers (rps16 intron and trnL-F region) were sequenced from the recent collections at Mt. Apo, Davao. Bayesian analysis of the combined plastid (rps16 and trnL-F) dataset strongly supported $(\mathrm{PP}=1.0)$ the inclusion of $M$. apoensis in the genus Mycetia and resolved M. cauliflora as its sister-taxa. A comprehensive description and botanical illustrations of $M$. apoensis as well as its conservation status based on IUCN criteria are here provided.
\end{abstract}

Keywords: Adenosacme, Mycetia, cpDNA, rps16, trnL-F, Philippine endemic, conservation

\section{INTRODUCTION}

Mycetia Reinw. of the family Rubiaceae is composed of about 45 species of small shrubs characterized by the corky white bark of older branches, the yellow or rarely white flowers and the fungus-like, snowy white, juicy berries [1]. The genus is distributed in tropical and subtropical Asia [2] and underwent several tribal affiliations from Mussaendeae [3], Hedyotideae

*To whom correspondence should be addressed balejan@yahoo.com /

grecebio.jonathan.alejandro@ust.edu.ph
[4], Isertieae [5], to the recently Argostemmateae [6]. In its current tribe, the genus Argostemma Wall. is resolved as its sister-taxa [7].

Currently, there are four Mycetia species [Mycetia apoensis (Elmer) Govaerts, Mycetia cauliflora Reinw., Mycetia javanica (Blume) Reinw. Ex Korth., and Mycetia mindanaensis (Elmer) Govaerts] known to be present in the Philippines [8]. Two of the Philippine endemic species (M. apoensis and M. mindanaensis) were previously under the genus Adenosacme Wall. but transferred to Mycetia based on 
morphology of herbarium specimens [9]. Moreover, Elmer [10] noted the close relationship between $M$. apoensis and $M$. cauliflora. There is a need to re-examine the morphology of the incompletely known $M$. apoensis.

In a recent botanical assessment of the Thomasian Angiosperm Phylogeny \& Barcoding Group (TAPBG) at Mt. Apo, Brgy. Ilomavis, Kidapawan City, the flowering and fruiting branches of $M$. apoensis were spotted from low to mid elevation of the mountain. The TAPBG took the opportunity to study the plant to: 1) confirm its generic affiliation inferred from two chloroplast makers (rps16 intron and trnLF region); 2) resolve whether $M$. apoensis is conspecific with M. cauliflora; and, 3) provide comprehensive descriptions, botanical illustration as well as the conservation status of M. apoensis.

\section{MAterials AND MEthods}

Two samples of M. apoensis (coded as 14-505 and 14-510) were collected at Mt. Apo National Park, through the Kidapawan-Magpet trail running through the Ilomavis Campsite (1,800 masl) and the Ko'ong Campsite (2,000 masl). Field photographs of the collected plants were taken. Leaf samples were placed in bags containing silica gel for DNA analysis [11]. Vegetative and reproductive branches were likewise collected for herbarium specimens. Preservation of reproductive parts was done by placing the parts in a plastic tube filled with commercial 70\% ethyl alcohol.

Silica-dried leaf samples were subjected to DNA extraction following the protocol of Qiagen DNeasy Plant Mini Kit (Qiagen, Germany). The rps16 intron was amplified and sequenced using rps16-1F/rps16-2R [12] while the trnL-F region was done using the primer pair c/f $[13,14]$. PCR reactions were performed on a Biometra $\mathrm{T}$ Gradient in volumes of $25 \mathrm{~mL}$ following the PCR parameters and mixture of Alejandro et al. [15-
17]. In all PCR runs, one sample was run with water instead of DNA as a negative control to test for contamination. Amplified DNA was purified with the QiaQuick PCR purification kit (Qiagen). All sequences were retrieved by the commercial services of Macrogen, Korea.

CodonCode Aligner v.3.0.1 was used to assemble and manually edit the forward and reverse sequences. Subsequently, the sequences were assembled using Seaview v4.5.2 for alignment and the excision of unnecessary bases. Additional DNA sequences were retrieved from Genbank (http:// www.ncbi.nlm.nih.gov/) representing members of the tribe Argostemmateae and species from closely related tribes such as Anthospermeae, Danaideae, Dunnieae, Knoxieae, Paederiae, Putorieae, Rubieae, Spermacoceae, and Theligoneae [18]. Colletoecema and Luculia were used as outgroups for character polarity. A Bayesian analysis of the aligned sequences was conducted using the software Mr. Bayes v3.2.2 [19]. The best performing evolutionary model was determined using MrModelTest v.2.3 [20] under three model selection criteria: a) Akaike Information Criterion (AIC) [21]; b) AICc (second order criterion of AIC); and, c) the Bayesian Information Criterion (BIC) [22]. Bayesian analysis was performed with a sample frequency of 1000, 4 parallel chains and 10 million generations.

\section{ResulTS AND DISCUSSION}

Sequence characteristics and variation. The combined (rps16 intron and trnL-F region) analysis included 38 sequences. Four new sequences of $M$. apoensis from the two molecular markers are newly published here. Matrix lengths of the two markers are 1,390 base pairs (bp) for the trnL-F marker and 1205 bp for the rps 16 intron. Although the rps 16 intron data set has the shorter matrix length, it yielded the highest number of informative characters (216 bp) compared to the trnL-F region (206 bp). The aligned combined data set consisted of 2,596 bp 
and a total of 422 informative characters. Alignment was without difficulty due to low genetic variation across the two cpDNA regions.

\section{Phylogenetic position of Mycetia apoensis. The} two sampled $M$. apoensis nested in a subgroup together with $M$. cauliflora. These two Mycetia species are sister to another subgroup containing $M$. gracilis, $M$. javanica, and $M$. malayana (Fig. 1). All five included Mycetia species formed a monophyletic clade with strong support $(\mathrm{PP}=1.0)$ (Fig. 1). This conforms with the transfer of Adenosacme apoensis made by Davis et al. [9]. Similar to the findings of Rydin et al. [18], our combined tree suggests that Neohymenopogon Bennet and Mouretia Pit. are closely related with the tribe Argostemmateae along with Mycetia and
Argostemma with high support ( $\mathrm{PP}=1.0)$. Both Neohymenopagon and Mouretia possessed persistent calyx lobes on the fruit that is also common in Argostemma and Mycetia [18].

Our combined tree (Fig. 1) suggests that $M$. apoensis is closely related to $M$. cauliflora with high support $(\mathrm{PP}=1.0)$. Sequence variation between $M$. apoensis and $M$. cauliflora is $7.70 \%$ for the $\operatorname{trnL}-\mathrm{F}$ region but $0.00 \%$ for the $r p s 16$ region. The relatively high divergence in the trnL-F region indicates that the two species are not conspecific in contrast to Elmer [10]. Based on morphology, $M$. apoensis is distinct from $M$. cauliflora in having more slender and somewhat longer calyx teeth [23], longer petiole and calyx, smooth yellowish gray bark, scurfy leaf, petiole and peduncle surfaces, 9-12 lateral nerve pairs,

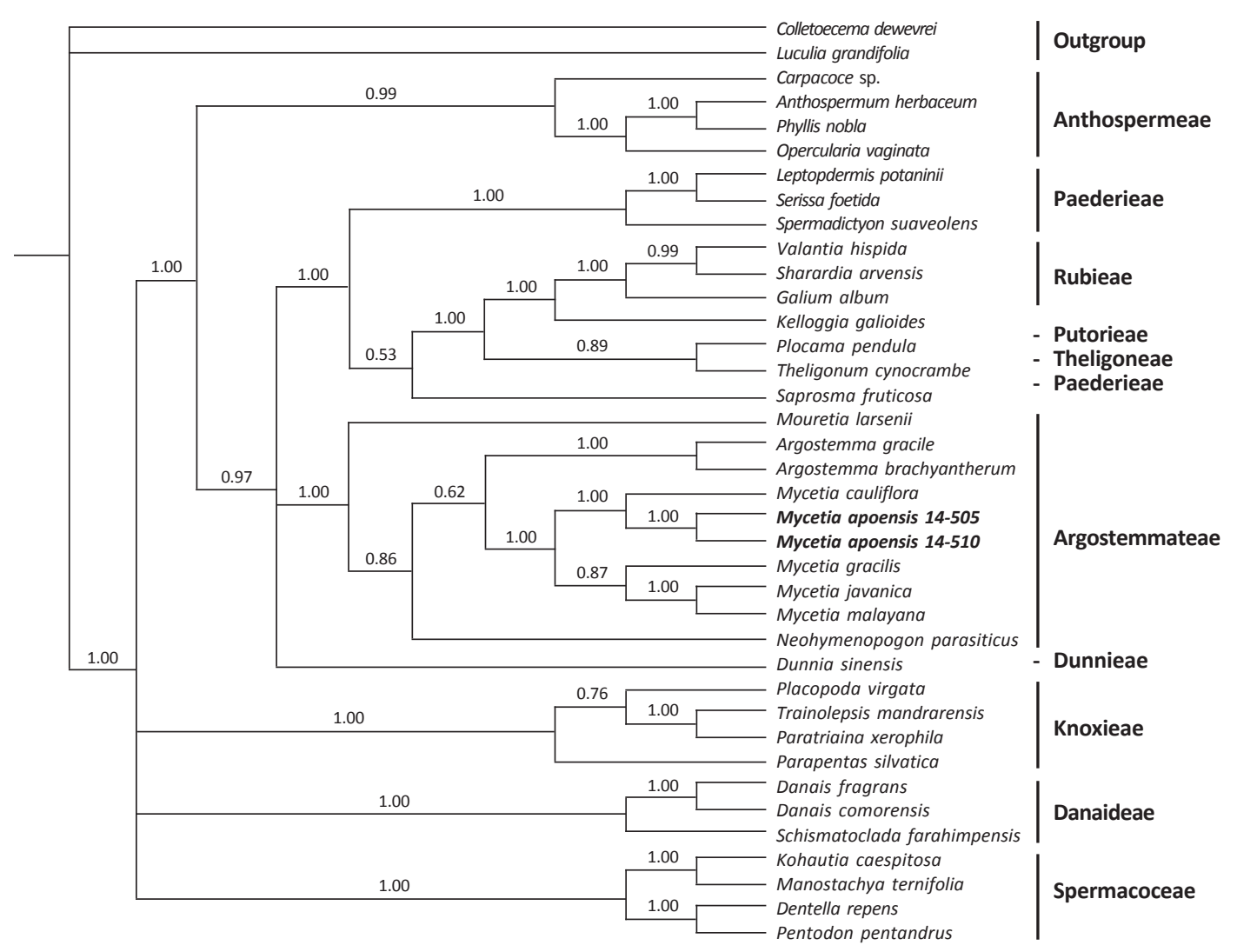

Figure 1. Majority rule consensus tree inferred from the combined rps16 and trnL-F sequence data. Numbers above nodes are Bayesian posterior probabilities. The highlighted text indicates Mycetia apoensis. 
a style which is short tomentose and glabrous towards the base and a subglobose fruit shape. Comparative morphology of the two species is presented in Table 1.
Taxonomy of Mycetia apoensis. This section provides the comprehensive vegetative and reproductive morphology as well as the

Table 1. Morphological comparison of $M$. cauliflora and M. apoensis

(The significant differences are in bold fonts.)

\begin{tabular}{|c|c|c|}
\hline & Mycetia cauliflora & Mycetia apoensis \\
\hline $\begin{array}{l}\text { Habit } \\
\text { Height }\end{array}$ & $\begin{array}{l}\text { Shrub } \\
1-2 \mathrm{~m}\end{array}$ & $\begin{array}{l}\text { Shrub } \\
1-2 \mathrm{~m}\end{array}$ \\
\hline $\begin{array}{l}\text { Stem } \\
\text { Thickness } \\
\text { Color }\end{array}$ & $\begin{array}{l}\text { Finger thick } \\
\text { White }\end{array}$ & $\begin{array}{c}3.9-7.5 \mathrm{~mm} \\
\text { Covered with a yellowish gray bark }\end{array}$ \\
\hline $\begin{array}{l}\text { Stipule } \\
\text { Texture } \\
\text { Shape } \\
\text { Length } \\
\text { Surface } \\
\end{array}$ & $\begin{array}{c}\text { Submembranous } \\
\text { Lanceolate-ovate } \\
2.5-6 \text { mm long } \\
\text { Subglabrous } \\
\end{array}$ & $\begin{array}{c}\text { Submembranous } \\
\text { Triangularly acuminate to lanceolate } \\
5.0-8.0 \text { mm long, } \\
\text { Subglabrous }\end{array}$ \\
\hline $\begin{array}{l}\text { Petiole } \\
\text { Length } \\
\end{array}$ & 2-10 mm long & 5.0-20 mm long \\
\hline $\begin{array}{l}\text { Leaf blade } \\
\text { Shape } \\
\text { Venation } \\
\text { Length } \\
\text { Width } \\
\text { Apex } \\
\text { Base } \\
\text { Surface } \\
\text { Lateral nerve pairs } \\
\end{array}$ & $\begin{array}{c}\text { Lanceolate or oblanceolate } \\
\text { Reticulate } \\
125-160 \mathrm{~mm} \\
35-70 \mathrm{~mm} \\
\text { Sharply pointed } \\
\text { Gradually tapered } \\
\text { Glabrous, puberulous } \\
\text { on the nerves beneath } \\
\mathbf{1 0 - 1 8} \text { pairs }\end{array}$ & $\begin{array}{l}\text { Broadly and more or less oblanceolate } \\
\text { Reticulate } \\
90-200 \mathrm{~mm} \\
30-50 \mathrm{~mm} \\
\text { Acuminate } \\
\text { Attenuate } \\
\text { Glabrous, dirty brown scurfy } \\
\text { 9-12 pairs }\end{array}$ \\
\hline $\begin{array}{l}\text { Inflorescence } \\
\text { Type }\end{array}$ & Thyrses & Loose cymose panicle \\
\hline $\begin{array}{l}\text { Pedicel } \\
\text { Length }\end{array}$ & $15 \mathrm{~mm}$ & $17-21 \mathrm{~mm}$ \\
\hline $\begin{array}{l}\text { Calyx } \\
\text { Shape } \\
\text { Length } \\
\text { Lobes number } \\
\text { Lobes length } \\
\end{array}$ & $\begin{array}{c}\text { Turbinate } \\
5 \text { mm long } \\
5 \\
\text { 1-2 mm long } \\
\end{array}$ & $\begin{array}{l}\text { Elliptic, the base much constricted } \\
\text { 7.0-8.0 mm long } \\
5 \\
\text { 3.0-3.5 mm long } \\
\end{array}$ \\
\hline $\begin{array}{l}\text { Corolla } \\
\text { Color } \\
\text { Shape } \\
\text { Length } \\
\text { Surface adaxial (above) }\end{array}$ & $\begin{array}{c}\text { Yellow } \\
\text { Funnel-tubular } \\
10 \mathrm{~mm} \text { long } \\
\text { Glabrous outside, rough inside }\end{array}$ & $\begin{array}{c}\text { Bright Yellow } \\
\text { Tubular } \\
12-13 \text { mm long } \\
\text { Glabrous except the strigose hairs in the } \\
\text { middle portion of the tube }\end{array}$ \\
\hline $\begin{array}{l}\text { Anther } \\
\text { Length/Width }\end{array}$ & $1.5 \mathrm{~mm}$ long & $2 \mathrm{~mm}$ long \\
\hline $\begin{array}{l}\text { Style } \\
\text { Length }\end{array}$ & $\begin{array}{l}\text { In long-styled form: } \\
4-8(-11) \mathrm{mm} \text { long } \\
\text { In short-styled form: } 2 \mathrm{~mm} \text { long } \\
\text { Puberulous }\end{array}$ & $\begin{array}{l}\text { 9-10 mm long } \\
\begin{array}{l}\text { Glabrous towards the base, } \\
\text { short tomentose }\end{array}\end{array}$ \\
\hline $\begin{array}{l}\text { Fruits } \\
\text { Presence of calyx lobes } \\
\text { Shape } \\
\text { Length } \\
\text { Width }\end{array}$ & $\begin{array}{l}\text { Crowned by the calyx lobes } \\
\text { Oblong } \\
\text { 10-15 mm long } \\
\text { 8-10 mm wide }\end{array}$ & $\begin{array}{l}\text { Crowned by the calyx lobes } \\
\text { Subglobose } \\
5-12.71 \mathrm{~mm} \\
5-12.45 \mathrm{~mm}\end{array}$ \\
\hline
\end{tabular}




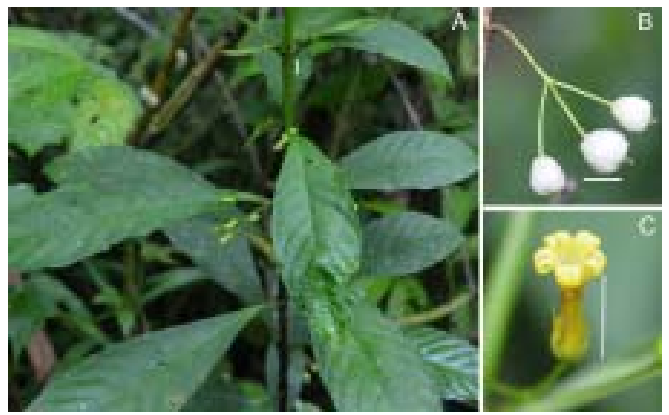

Figure 2. Mycetia apoensis. (A) Habit, (B) fruits, and (C) flower. Scale bars in A, B, and C indicate 1 $\mathrm{cm}$. Photos taken by Villanueva JCC and Alejandro GJD.

distribution, habitat and conservation status of M. apoensis.

\section{Mycetia apoensis (Elmer) Govaerts, Fig. 2 and} Fig. 3

Type: Philippines, Mindanao, District of Davao, Todaya (Mt. Apo), v.1909, Elmer 10504 (K!).

Lax shrub, 1-2 m tall; stem, 3.9-7.5 mm thick, terete, subglabrous and covered with a smooth yellowish gray bark; branches are sparingly rebranched and reclinate. Leaves thin, paler green beneath, mainly horizontal, flat or only the tips recurved, opposite, glabrous or dirty brown scurfy, membranous or thinly chartaceous, drying green, broadly or more or less oblanceolate, entire margins, 9.0-20 cm long and $3.0-5.0 \mathrm{~cm}$ wide just above the middle apex acuminate, base attenuate; nerves more prominent beneath, 9-12 on each side of the prominent midvein, reticulate crossbars quite evident; petiole slender, sub-glabrous or minutely scurfy brown, $0.5-2.0 \mathrm{~cm}$ in length, stipules submembranous and subglabrous, 5.0$8.0 \mathrm{~mm}$ long, 1.8-2.5 mm wide, entire, brown when dry, triangularly acuminate to lanceolate. Infloresence a loose cymose panicle, descending usually in the leaf axis, once or twice rebranced, 3.5-5.0 cm long and wide; peduncle subcompressed, dirty brown scurfy, arising from

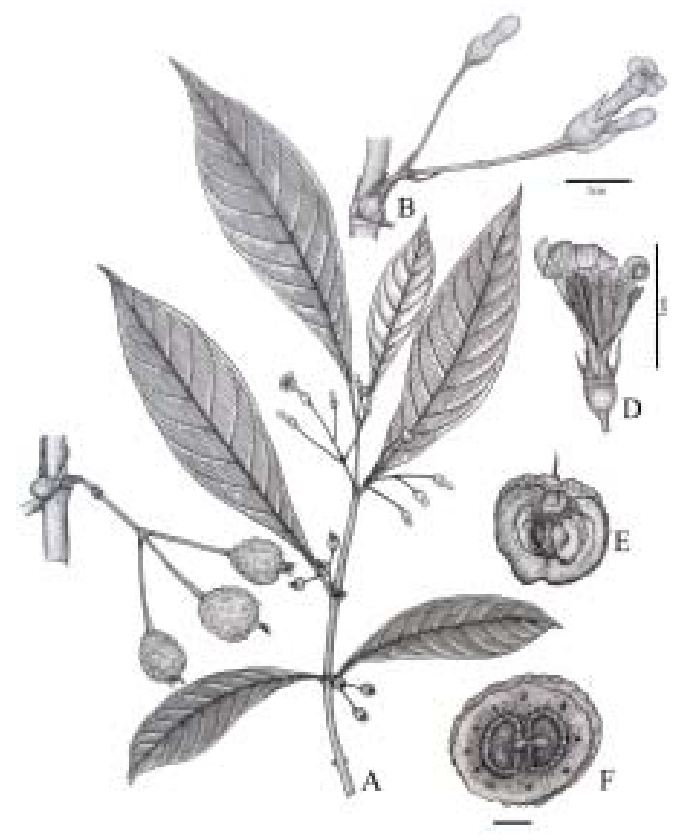

Figure 3. Mycetia apoensis. (Elmer) Govaerts. (A) flowering branch, (B) Inflorescence (C) infructescence, (D) open corolla showing anther and style, (E) longitudinal section of fruit, and (F) cross section of ovary. From Villanueva et al. 14-505 \& 14-510 (USTH). Drawn by Diego N.

a whorl of persistent, dry, straw-colored, 2.0$3.0 \mathrm{~mm}$ long triangular bracts, bearing 1 or 2 similar whorls, and about 11-14 mm long, pedicels similar in vestiture, very slender, 17$21 \mathrm{~mm}$ long, subtended by similar bracts that are chiefly in whorls of three's, the larger ones occasionally branched; calyx 7-8 mm long, 2.7$3.2 \mathrm{~mm}$ wide, elliptic, the base is much constricted, rough puberulent or finely scabrous, abruptly divided into five very thin, $3.0-3.5 \mathrm{~mm}$ long calyx lobes which are triangular at the base and very narrowly lanceolate at the apex; corolla bright yellow, 12-13 mm long, tubular, tube strigose adaxially, subglabrous abaxially, 9-10 mm long; lobes 5 triangularly oblong, glabrous adaxially and subglabrouse abaxially, valvate; stamens 5 , just below the throat; filament glabrous, $0.5-0.6 \mathrm{~mm}$ long, adnate to the corolla; anthers oblong, $2.0 \mathrm{~mm}$ 
long, dorsifixed, acute at apex, style slightly exceeding the corolla, 9-10 mm and two-forked at apex although occasionally easily separating clear to the narrowed base, glabrous toward the base, short tomentose otherwise; fruit subglobose 5-12.71 mm long 5-12.45 mm wide, slightly scabrous, two-celled, juicy, snow-berry white, sunken at apex and surmounted by the five persistent calyx teeth; seeds $0.5 \mathrm{~mm}$ across, dark brown, angularly flattened, very numerous in two dense masses.

Distribution and habitat: Restricted to Mt. Apo National Park, Davao and Mt. Hibok Hibok, Camiguin; from 1200-1300 masl in a very moist densely forested flats.

Conservation status of Mycetia apoensis. This species is restricted to Mt. Apo National Park at 1200-1300 masl and Mt. Hibok Hibok, Camiguin. It was also reported that the same species was collected in Mindoro [10]. Based on the IUCN Red List Categories and Criteria [24], M. apoensis is categorized as Vulnerable [VU B2ab(i)]; B2, area of occupancy estimated to be less than 2,000 km² (area of Mt. Apo: $550 \mathrm{~km}^{2}$ and area of Mt. Hibok Hibok: $238 \mathrm{~km}^{2}$ ); a, severely fragmented or known to exist at no more than 10 locations (M. apoensis: known to exist at two locations); b(i), continuing decline, observed, inferred or projected, in extent of occurrence (M. apoensis: a decrease in the extent of occurrence of this species is inferred due to the lack of recent records indicating its presence in Mindoro).

\section{CONCLUSION}

Molecular and morphological analyses confirm the identity and distinctness of $M$. apoensis over M. cauliflora.

\section{ACKNOWLEDGMENT}

We thank the UST Research Center for Natural and Applied Sciences for the use of facilities. GJDA thanks the DOST-Philippine Council for
Health, Research and Development for the research funding.

\section{REFERENCES}

[1] Gideon O, Tjitrosoedirdjo S, \& Veldkamp J. Notes on Mycetia. Floribunda 1988; 1:17-20.

[2] Wu ZY, Raven PH, Hong DY (Eds.). Flora of China, Vol. 19 (Cucurbitaceae through Valerianaceae, with Annonaceae and Berberidaceae), pp. 242-247. (St. Louis: Science Press [Beijing] and Missouri Botanical Garden Press, 2011).

[3] Schumann K. Rubiaceae, Die Natürlichen Pflanzenfamilien. In: Engler A \& Prantl K (Eds.) Ergänzungshef (Vol. 4), pp. 1-156. (Leipzig: Engelmann, 1891).

[4] Verdcourt B. Remarks on the classification of the Rubiaceae. Bulletin du Jardin Botanique de l'État 1958; 28:209-290.

[5] Robbrecht E. Supplement to the 1988 outline of the classification of the Rubiaceae, index to the genera. In: Robbrecht E (Ed.) Advances in Rubiaceae Macrosystematics. Opera Botanica Belgica 1994; 6:173-196.

[6] Alejandro GJD \& Liede S. The Philippine Rubiaceae genera: Updated synopsis in intkey databases of the delta system. Blumea 2003; 48:261-277.

[7] Bremer B. Phylogenetic studies within Rubiaceae and relationships to other families based on molecular data. Opera Botanica Belgica 1996; 7:33-50.

[8] Pelser P, Barcelona J, \& Nickrent D (Eds.). Co's Digital Flora of the Philippines, 2011. Retrieved from www.philippineplants.org on 16 July 2016.

[9] Davis A, Govaerts R, \& Rusham M. Nomenclatural changes in preparation for a World Rubiaceae Checklist. Botanical Journal of the Linnean Society 2008; 157:115-124.

[10] Elmer A. Adenosacme. Leaflets of Philippine Botany 1911; 3:1001-1003.

[11] Chase MW \& Hills HH. Silica gel: An ideal material for preservation of leaf samples for DNA studies. Taxon 1991; 40:215-220.

[12] Oxelman B, Lide'N, M, \& Berglund D. Chloroplast rps16 intron phylogeny of the tribe Sileneae (Caryophyllaceae). Plant Systematics and Evolution 1997; 184:393-410.

[13] Taberlet P, Gielly L, Pautou G, \& Bouvet J. Universal primers for amplification of three noncoding regions of chloroplast DNA. Plant Molecular Biology 1991; 17:1105-1109. 
[14] Bremer B, Bremer K, Heidari N, Erixon P, Olmstead RG, Anderberg AA, Källersjö M, \& Barkhordarian E. Phylogenetics of asterids based on 3 coding and 3 non-coding chloroplast DNA markers and the utility of non-coding DNA at higher taxonomic levels. Molecular Phylogenetics and Evolution 2002; 24:274-301.

[15] Alejandro GJD, Mieve U, Uy M, Mouly A, Thiv M, \& Liede-Schumann S. Molecular support of the classification of Greeniopsis Merr. In Aleisanthieae (Rubiaceae), with a revision of the genus. Taxon 2010; 59:1547-1564.

[16] Alejandro GJD, Mieve U, Mouly A, Thiv M, \& LiedeSchumann S. Molecular phylogeny and taxonomic revision of the Philippine endemic Villaria Rolfe (Rubiaceae). Plant Systematics and Evolution 2011; 296:1-20.

[17] Alejandro GJD, Santos LA, Hsu HW, Mejillano MS, Santor PJ, \&Amoroso V. Molecular phylogeny of the genus Bikkia (Rubiaceae) including a new endemic Philippine inland forest species Bikkia montoyae. Philippine Science Letters 2014; 7:88-96.
[18] Rydin C, Razafimandimbison SG, Khodabandeh A, \& Bremer B. Evolutionary relationships in the Spermacoceae alliance (Rubiaceae) using information from six molecular loci: insights into systematic affinities of Neohymenopogon and Mouretia. Taxon 2009; 58:793-810.

[19] Huelsenbeck JP \& Ronquist F. MRBAYES: Bayesian inference of phylogenetic trees. Bioinformatics 2001; 8:754-755.

[20] Nylander JAA. MrModeltest v2 (Program distributed by the author). (Evolutionary Biology Centre, Uppsala University, 2004).

[21] Akaike H. A new look at the statistical model identification. IEEEE Transactions on Automatic Control 1974; 19:716-723.

[22] Schwartz G. Estimating the dimensions of a model. Annals of Statistics 1978; 6:461-464.

[23] Merrill ED. New or noteworthy Philippine plants. Philippine Journal of Science 1915; 10:105.

[24] IUCN. Categories and criteria (Version 3.1). (IUCN: Gland, Switzerland, 2001). 